\title{
First report of the powdery mildew Podosphaera xanthii on Gynura bicolor
}

\author{
Yuan-Min Shen ${ }^{1} \cdot$ Tung-Chin Huang $^{1} \cdot$ Hsing-Lung Liu ${ }^{1} \cdot$ Chia-Hung Chao ${ }^{1}$
}

Received: 28 June 2015 / Accepted: 5 August 2015 / Published online: 13 August 2015

(C) Australasian Plant Pathology Society Inc. 2015

\begin{abstract}
In April-May 2015, powdery mildew was observed on stems and leaves of hongfengcai (Gynura bicolor), a perennial vegetable crop, in central Taiwan. Morphological and molecular characteristics determined this fungus as Podosphaera xanthii, which is reported on the plant genus Gynura for the first time.
\end{abstract}

Keywords Erysiphales · Erysiphaceae · powdery mildew · Asteraceae $\cdot$ vegetables $\cdot$ rDNA spacer sequence

Hongfengcai (Gynura bicolor), also known as Okinawan spinach, is a perennial plant consumed as a vegetable in Asian countries. The crop is grown in open fields or in net houses in Taiwan under both conventional and organic farming systems.

During April and May 2015, powdery mildew was observed on $G$. bicolor at one side of the edge of a net house in Puyan Township, Changhua County, Taiwan. Symptoms appeared as thin white patches on stems and on upper side of leave surfaces (Fig. 1). Lower part of the plants was found to be more susceptible. Under microscopic observation, hyphal appressoria of the fungus were indistinct or nippleshaped. Conidiophores measured 103.8 to $150.0 \mu \mathrm{m}$ long $\times$ 11.3 to $13.8 \mu \mathrm{m}$ wide, and were followed by 2 to 5 immature conidia with crenate edges. The foot-cells in conidiophores were cylindrical, 50.0 to $75.0 \mu \mathrm{m}$ long, and constricted at the base (Fig. 2). Conidia were hyaline, ellipsoid, with an

Yuan-Min Shen

shenym@tdais.gov.tw

1 Plant Protection Laboratory, Taichung District Agricultural Research and Extension Station, Dacun, Changhua, Taiwan average length and width of 32.9 (26.3 to 40.0$) \times 19.1(14.4$ to 24.4$) \mu \mathrm{m}(n=58)$, with a length-to-width ratio of 1.2 to 2.4 . Distinct fibrosin bodies were observed in conidia (Fig. 3). Chasmothecia were absent on the diseased samples. Based on the morphological characteristics, the fungus was considered to be Podosphaera xanthii (Braun and Cook 2012). A voucher specimen (TNM No. F0028732) was deposited in the herbarium of the National Museum of Natural Science, Taichung, Taiwan.

To confirm the identification, DNA from symptomatic tissues was extracted with a Plant Genomic DNA Extraction Miniprep Kit (Viogene, Taiwan). PCR amplification of the Internal Transcribed Spacer (ITS) region of ribosomal DNA was performed with the primer pairs ITS1/PM6 and PM5/ ITS4 (Takamatsu and Kano 2001; White et al. 1990). The resulting 558 bp sequence was deposited in GenBank as Accession No. KT210086. The sequence similarity was $99.8 \%$ (557/558) compared with that of P. xanthii (AB525914)

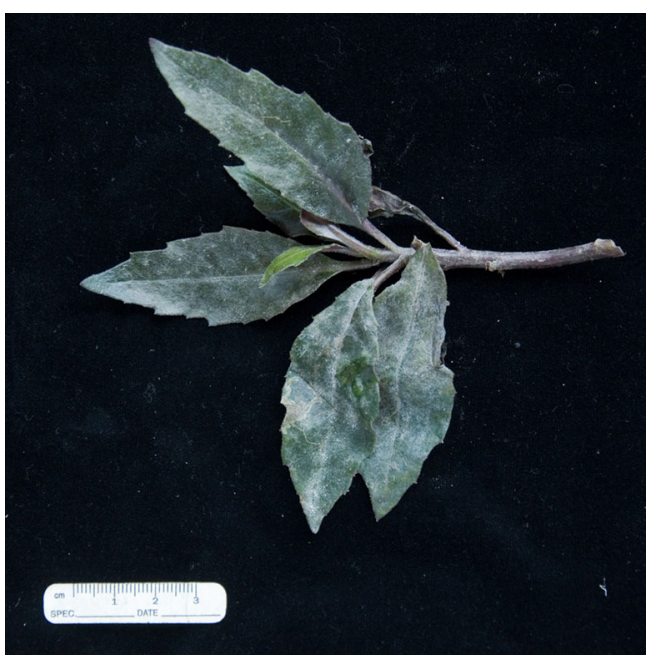

Fig. 1 Symptoms of powdery mildew on hongfengcai (Gynura bicolor) 


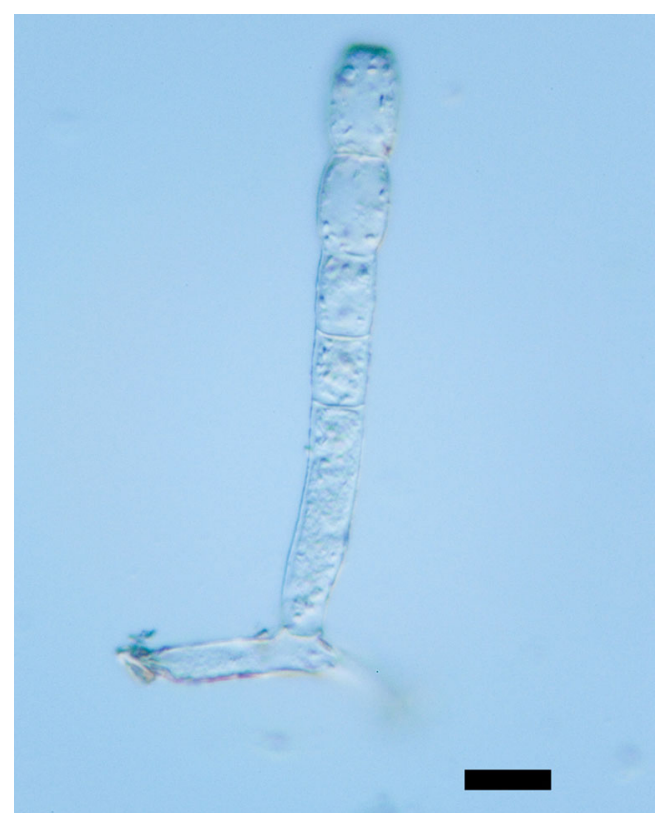

Fig. 2 Conidiophore and immature conidia of Podosphaera xanthii (TNM No. F0028732). Bar $=20 \mu \mathrm{m}$

infecting a plant in Asteraceae family (Takamatsu et al. 2010), revealing that the fungus clustered with the species complex of P. xanthii (Braun and Cook 2012).

According to our further surveys, no powdery mildew symptoms were found at nearby commercial hongfengcaigrowing fields in Changhua County. The observation indicated the disease was not widespread. However, pumpkin leaves with powdery mildew symptoms were seen adjacent to the place where G. bicolor infected by P. xanthii was first discovered (Fig. 4). The powdery

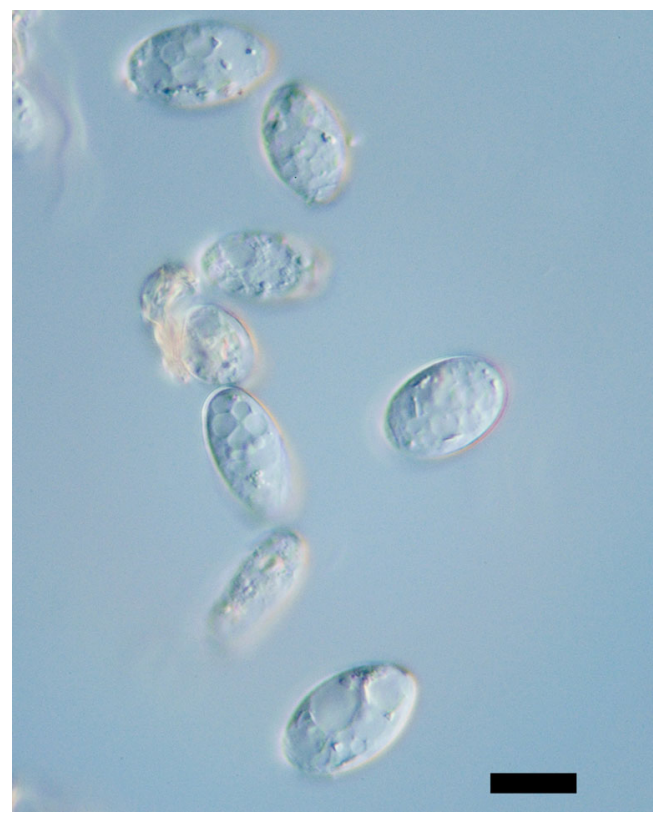

Fig. 3 Conidia of Podosphaera xanthii (TNM No. F0028732). Bar=20 $\mu \mathrm{m}$

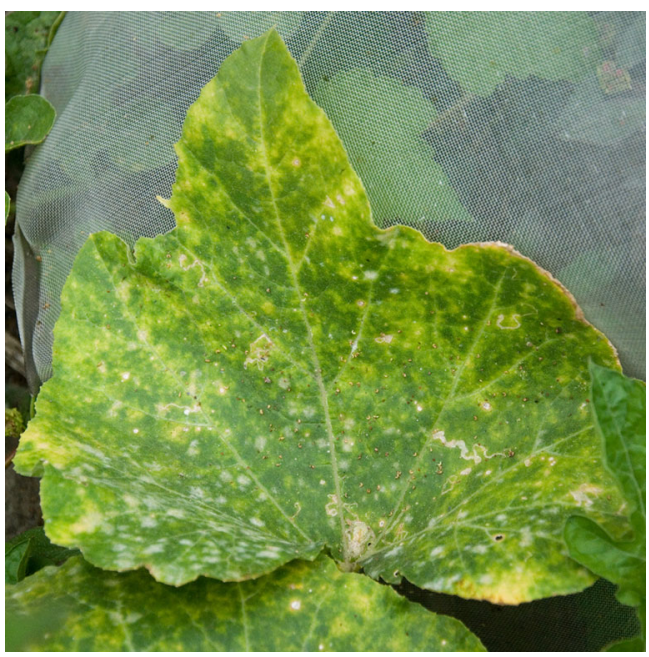

Fig. 4 Powdery mildew symptoms on pumpkin leaf near Gynura bicolor plants infected by Podosphaera xanthii

mildew on the pumpkin plants was identified as $P$. xanthii based on its ITS sequence (GenBank Accession No. KT210087). This result suggests the possibility of the pathogen to spread from a cucurbitaceous host to other hosts which is not commonly seen to be infested with the fungus. $P$. xanthii is reported to infect angiosperm species in Asteraceae, Cucurbitaceae, Fabaceae, Scrophulariaceae, and Solanaceae, etc. (Braun and Cook 2012; Farr and Rossman 2015). The pathogen was recently confirmed to incite diseases on melon, papaya and bitter gourd in Taiwan (Huang and Wang 2007; Tsay et al. 2011; Liu and Kirschner 2015). To our knowledge, this is the first occurrence of the powdery mildew $P$. xanthii on hongfengcai in Taiwan. Remarkably, this is the first record of $P$. xanthii causing powdery mildew on the plant genus Gynura.

\section{References}

Braun U, Cook RTA (2012) Taxonomic manual of the Erysiphales (powdery mildews). CBS-KNAW Fungal Biodiversity Centre, the Netherlands

Farr DF, Rossman AY (2015) Fungal database. Systematic Botany and Mycology Laboratory, ARS, USDA. http://nt.ars-grin.gov/ fungaldatabases/. Accessed 22 June 2015

Huang JH, Wang YH (2007) The races of Podosphaera xanthii causing melon powdery mildew in Taiwan. J Taiwan Agric Res 56:307-315

Liu WA, Kirschner R (2015) First report of powdery mildew caused by Podosphaera xanthii on wild bitter gourd in Taiwan. Plant Dis 99: 726

Takamatsu S, Kano Y (2001) PCR primers useful for nucleotide sequencing of rDNA of the powdery mildew fungi. Mycoscience 42:135139

Takamatsu S, Niinomi S, Harada M, Havrylenko M (2010) Molecular phylogenetic analyses reveal a close evolutionary relationship 
between Podosphaera (Erysiphales: Erysiphaceae) and its rosaceous hosts. Persoonia 24:38-48

Tsay JG, Chen RS, Wang HL, Wang WL, Weng BC (2011) First report of powdery mildew caused by Erysiphe diffusa, Oidium neolycopersici, and Podosphaera xanthii on papaya in Taiwan. Plant Dis 95:1188
White TJ, Bruns TD, Lee S, Taylor JW (1990) Amplification and direct sequencing of fungal ribosomal RNA genes for phylogenetics. In: Innis MA, Gelfand DH, Sninsky JJ, White TJ (eds) PCR Protocols: a guide to methods and applications. Academic Press, Inc., San Diego, pp 315-322 